DOI https://doi.org/10.30525/978-9934-588-80-8-1.7

\title{
ОСОБЛИВОСТИ ВПЛИВУ СПОРТИВНОЇ ДІЯЛЬНОСТІ НА ФОРМУВАННЯ ОСОБИСТОСТІ ЛЮДИНИ
}

\author{
Дейнеко А. X. \\ кандидат наук з фізичного виховання і спорту, \\ дочент кафедри гімнастики, \\ таниювальних видів спорту та хореографії \\ Харківська державна академія фізичної культури
}

Біленька I. Г.

старший викладач кафедри гімнастики, танцювальних видів спорту та хореографіі

Харківська державна академія фізичної культури

Красова I. B.

старший викладач кафедри гімнастики, танцювальних видів спорту та хореографії Харківська державна академія фізичної культури м. Харків, Україна

Метою роботи $є$ аналіз впливу спортивної діяльності на формування особистості людини. Поняття «особистість» допомагає охарактеризувати в людині соціальну основу іiі життєдіяльності, ті властивості і якості, які людина реалізує в соціальних зв'язках, соціальних інститутах, культурі, тобто в суспільному житті, в процесі взаємодії $з$ іншими людьми [3, с. 102; 4, с. 232]. Поняття «особистість» широко використовується як у різних суспільних науках, так і в повсякденному житті. Коли характеризують людину, то говорять про неї або як про особистість, або як про індивіда, або як про індивідуальність. У психології ці поняття розрізняються. Вихіднім є поняття «людина». Найсуттєвіша ознака людини - це суспільне життя і відносини, колективна трудова діяльність, які змінили іiі та підкорили собі іiі природну індивідуальність. Конкретну людину з усіма ії характерними ознаками позначають поняттям «індивід». Поняття «особистість» більш вузьке ніж поняття «людина». Особистість - системна соціальна характеристика індивіда, що формує предметну діяльність та спілкування i зумовлює причетність до суспільних відносин. Поняття «особистість» на відміну від поняття «людина» - соціальна характеристика людини, що вказує на ті якості, які формуються під впливом суспільних 
відносин, спілкування 3 іншими людьми. Як особистість людина формується в соціальній системі шляхом цілеспрямованого i продуманого виховання. Особистість визначається мірою накопичення суспільного досвіду і мірою віддачі суспільству посильного внеску в скарбницю матеріальних і духовних цінностей. Щоб стати особистістю, людина повинна в діяльності, на практиці проявляти, розкривати свої внутрішні властивості, закладені природою і сформовані в ній життям i вихованням [9, с. 306].

Аналіз науково-методичної літератури показав, що фізична культура та спорт - важливі дієві засоби виховання особистості [5, с. 127; 6, с. 37]. Спеціалісти (Волков Л.В., 2002; Лубишева Л.І., 2007; Сутула В.О., 2012) звертають увагу на те, що фізкультурно-спортивна діяльність об'єднує в собі прагнення до високого спортивного результату, розвитку фізичних якостей, спрямована на виховання людини в якій поєднується духовне багатство і моральна чистота. Формування особистості юних та дорослих спортсменів тісно пов'язане iз самовихованням. Аналізуючи свої вчинки, ставлячи перед собою значні цілі, спортсмен свідомо виховує в собі бажані якості особистості, насамперед вольові якості та риси характеру: рішучість, сміливість, наполегливість, дисциплінованість тощо. Як правило, високих результатів, особливо в професійному спорті, досягають ті, хто самостійно і багато працює над собою [11, с. 132]. Більше того, на думку Платонова В. Н. успіх у спорті значною мірою залежить від індивідуальних психологічних особливостей спортсмена, а конкретні види спорту пред'являють до нього певні вимоги і разом 3 тим формують якості особистості, необхідні для успішного здійснення змагальної діяльності [8, с. 536]. Таким чином, спорт дозволяє свідомо, цілеспрямовано і вельми ефективно впливати на найрізноманітніші фізичні, психічні, духовні якості і здібності спортсмена, і як діяльність відновлює певні базові механізми формування особистості, включає індивіда у соціальні спільноти i громадські організації, як повноправного члена суспільства і формує певні соціальні відносини.

Виділяючи основні риси спорту, Мамаєва О. В. і Мамаєв Д. Ю. відзначають змагальність, тобто відносини між спортсменами в процесі змагань. У ході змагань проявляються особистісні якості, професійні вміння, інтелект, воля до перемоги спортсменів, а також знання і досвід тренерів, рівень розвитку цілого ряду наук, рівень технічного обладнання, застосування різних спортивних засобів. На їх думку, змагальна функція, що виражає в концентрованому вигляді соціокультурну сутність спорту, втілюється в найрізноманітніших аспектах спортивної діяльності [7, с. 59]. Внаслідок цього рухові 32 
вправи повинні розглядатися лише як матеріал діяльно-практичного діалогу тренера і спортсмена і виступати в якості засобів самореалізації особистості. У цьому випадку увага тренера має бути спрямована на розвиток особистості як єдиного соціального та природного, духовного i тілесного, а не тільки на формування організму як на систему безособових фізіологічних і біологічних механізмів. Орієнтація на людську особистість як на ціль і суб'єкта діяльності відкриває новий ракурс для визначення засобів і способів спортивної діяльності.

У спортивній діяльності особливості особистості поєднуються 3 вибором стратегії їх реалізації: стратегією індивідуалізації та стратегією звільнення від недоліків. Стратегія індивідуалізації передбачає всебічне врахування індивідуальних особливостей особистості, формування індивідуального стилю діяльності, в якому не просто враховується весь комплекс властивостей психіки спортсмена, але і напрацьовуються прийоми діяльності, в яких найбільш вигідним способом реалізовано конкретні особливості. Стратегія звільнення від недоліків та опирання на сильні сторони психіки не менш відома та прийнятна для спорту. Вона базується на пластичності властивостей нервової системи які, як відомо, пластичні до певної міри. Проте діапазон пластичності існує і цілком можливим $\epsilon$ те, що спортсмен із слабкою нервовою системою, або несміливий, через деякий час стане більш сміливим та навчиться діяти в стандартних спортивних ситуаціях, як і людина 3 сильною нервовою системою. Те ж можна сказати і про характер, і про здібності. Можливо більш вдалим було б знайти для спортсмена вид спорту, амплуа, виробити індивідуальний стиль діяльності, або піти шляхом викорінення недоліків, виховання бажаних для спорту особливостей особистості, долаючи природний «опір» його природної психічної організації. Відповідно до ідей самореалізації особистості завданнями тренера i самого спортсмена стають: забезпечення максимальної реалізації задатків та обдарованості у відповідному виді діяльності, знаходження себе у світі спорту, знаходження шляху до застосування своїх сил, особливостей та можливостей. Якщо цього не відбувається, тоді у спортсмена $з$ часом утворюється особистісний синдром, який не сприяє успішному вирішенню змагальних завдань, призводить до невиправданої тривожності, високої ймовірності зриву, скутості в поведінці, незадоволення собою. Особистісний синдром - це певне поєднання декількох особливостей особистості, в яких може бути єдиний механізм виникнення $[1$, с. $14 ; 7$, с. 60$]$.

Таким чином, однією з умов всебічного розвитку особистості $\epsilon$ іiі фізична підготовленість, як результат фізичного виховання, заняття спортом. Формування особистості, яка поєднує в собі духовне багатство, 
моральну чистоту і фізичну досконалість $є$ програмою виховання людей у сучасному суспільстві. Спорт впливає на формування характеру людини, тобто тих особливостей особистості, які відбуваються на вчинках і відносинах з іншими людьми та зовнішнім світом.

\section{Література:}

1. Апциаури Л. Ш. Спорт как социальное явление и фактор социализации личности. Теория и практика физической культуры. Тбилиси, 2003. № 1. С. 12-14.

2. Волков Л.В. Теория и методика детского и юношеского спорта. Киев : Олимпийская литература, 2002. 295 с.

3. Герасимчук А. А. Соціологія : навч. посібник. Київ : Видавництво Європейського ун-ту, 2004. 246 с.

4. Дейнеко А. Х., Красова I.В. Загальна характеристика поняття особистості та вплив спортивної діяльності на іiі формування. Украӥна в гуманітарних і сочіально-економічних вимірах : матеріали III Всеукраїнської наукової конференції, м. Дніпро, 30-31 березня 2018 p. C. $232-234$.

5. Клименко В. В. Психологія спорту. Київ : 2007. 427 с.

6. Лубышева Л. И. Интеграция спортивного и олимпийского воспитания в образовательном пространстве школы. Наука в олимпийском спорте. Москва : 2007. № 2. С. 36-40.

7. Мамаєва О. В., Мамаєв Д. Ю. Фізична культура і спорт як чинники соціалізації особистості. Педагогіка, психологія та медикобіологічні проблеми фізичного виховання i спорту. Луганськ : 2010. № 7. C. 58-60.

8. Платонов В. Н. Система подготовки спортсменов в олимпийском спорте. Общая теория и ее практические приложения : учебник [для тренеров в 2 кн.], Киев, 2015. Кн. 2. 752 с.

9. Степанов О. М., Фіцула М. М. Основи психології і педагогіки : навчальний посібник. Київ : 2006. 520 с.

10. Сутула В.О. Базові ознаки фізичної культури особистості. Духовність особистості: методологія, теорія і практика : зб. наук. пр. СНУ ім. В. Даля. Луганськ, 2012. № 6 (53). С. 186-192.

11. Федик О. В. Психологія спорту : матеріали для самопідготовки до семінарських занять для студентів спеціальності «Психологія». Івано-Франківськ : 2013. 226 с. 